\title{
PREFERENCE OF TRICHODINIDS (Ciliata, Peritrichia) OCCURRING ON FISH-POND CARP FOR PARTICULAR ORGANS AND SOME MORPHOLOGICAL IMPLICATIONS
}

\author{
NIKOLIĆ VERA*, SIMONOVIĆ $P^{*}$ and POLEKSIĆ VESNA** \\ * Faculty of Biology, Institute of Zoology, Belgrade, \\ ** Faculty of Agriculture, Department of Animal Breeding, Belgrade \\ (Received 22. July 2002)
}

The present study describes the preference of Trichodinids for skin or gills of fish-pond carp. Differences in localization of trichodinids were analysed by the Mann-Whitney $U$ and $\chi^{2}$ tests. For histological examination gills were fixed in $4 \%$ formaldehyde and processed using standard techniques. Trichodinella epizootica and T. subtilis parasitised exclusively gills. The occurrence of Trichodina acuta was far more frequent on the skin and that preference appeared to be statistically significant. Trichodina nobilis was found on both skin and gills with a significant preference for skin; Trichodina nigra was found on both target organs. Trichodinella epizootica damaged the gill epithelia and induced enforced mucous secretion. carp

Key words: localization, target organs, Trichodinidae, fish-pond

\section{INTRODUCTION}

The representatives of the family Trichodinidae have been commonly recorded on fish fry (Allamuratov 1986). Reports on the trichodinids of fish-pond reared carp from Bulgaria (Grupcheva \& Golemansky 1986), the former Czechoslovakia (Lom \& Dykova 1989), the former USSR (Bauer et al. 1973; Tlenbekova \& Dzevickaya 1986), Finland (Halmetoja et al. 1992) and Yugoslavia (Nikolić \& Simonović 1996) revealed a broad variety in regard to both their impact on fishproduction and their relationship with the host. Kabata (1985) and Roberts (1978) considered them strong pathogens, while Lom \& Dykova (1989) found them to be pure commensals.

Whatever effect particular trichodinids have on their host, their specificity for particular target organs will influence it.

\section{MATERIAL AND METHODS}

Materials were collected from the Ečka and Uzdin fish-ponds in Banat (Serbia). A total of 346 yearlings of pond-reared carp were analysed; of these 182 were from the Ečka fish-pond, and 164 from the Uzdin fish-pond. Squash slides of skin and gill epithelium were made from live specimens. Slides were impregnated by 
silver-nitrate according to the modified method of Klein-Foissner. They were examined under the microscope (400 x magnification). Differences in localization of trichodinids were analysed by Mann-Whitney U and $\chi^{2}$ tests (Sokal \& Rohlf, 1981).

For histological examination gills were fixed in $4 \%$ formaldehyde, and processed using standard techniques with haematoxylin and eosin staining.

\section{RESULTS AND DISCUSSION}

The species Trichodina acuta Lom (Fig. 1b), Trichodina nobilis Chen (Fig. 1c) and Trichodinella epizootica (Raabe) (Fig. 1e) were found on carp in both fishponds, whereas the species Trichodina nigra Lom (Fig. 1a) and Trichodinella subtilis Lom (Fig. 1d) were found only in the Ečka fish-pond.
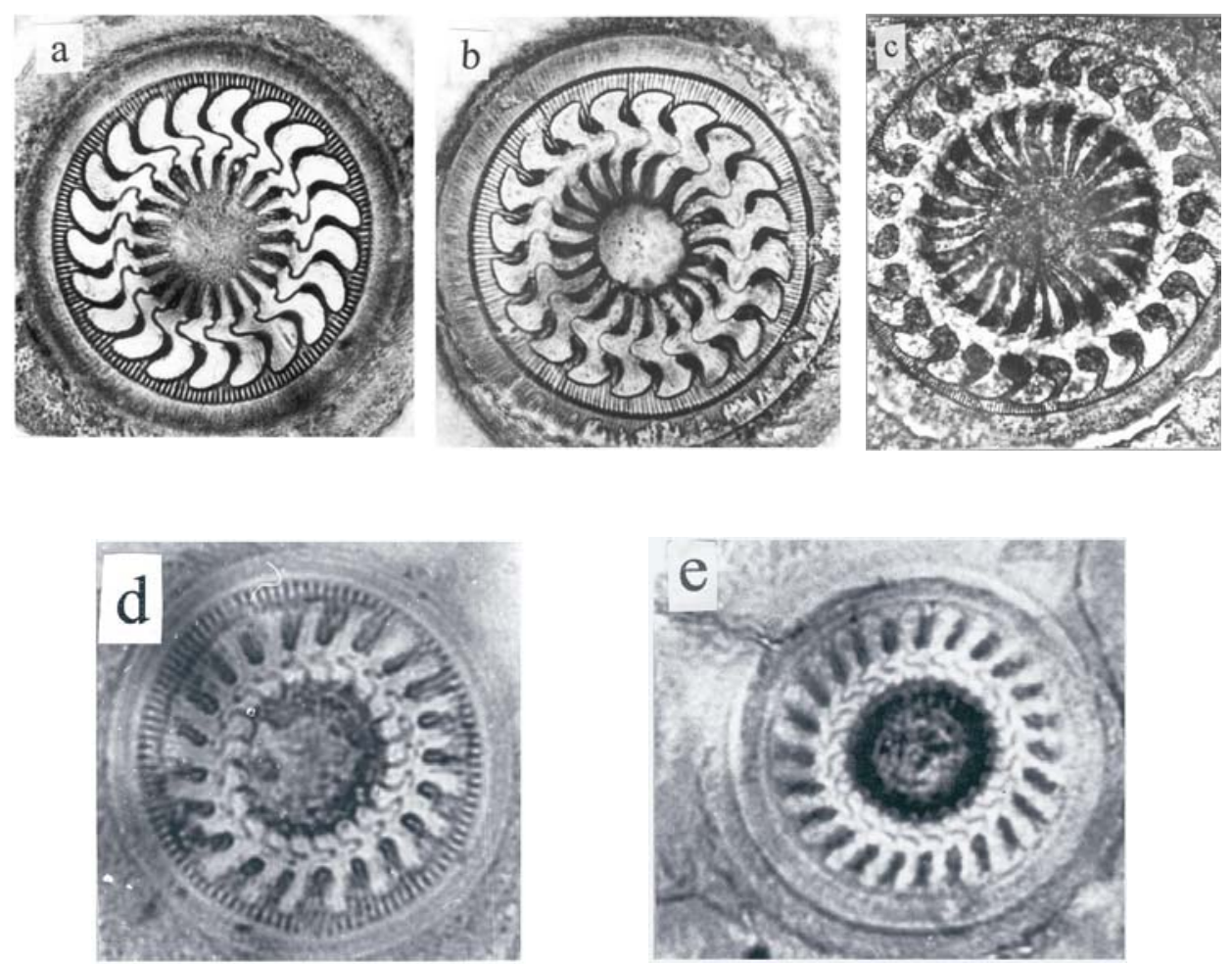

Figure 1. Photomicrophs of silver-impregnated trichodinids: a) Trichodina nigra b) Trichodina acuta c) Trichodina nobilis d) Trichodinella subtilis e) Trichodinella epizootica; scale bar equals $20 \mu \mathrm{m}$. 
Acta Veterinaria (Beograd), Vol. 53. No. 1, 41-46, 2003

Nikolić Vera et al. Preference of trichodinids (Ciliata, Peritrichia) occurring on

fish-pond carp for particular organs and some morphological implications

Table 1: Results on the preference of trichodinids for target organs (skin and gills) at two fish-ponds analysed by Mann-Whitney $U$ test $(\mathrm{t})\left({ }^{* * *}, \mathrm{p}<0.001 ;{ }^{* *}, \mathrm{p}<0.01\right)$ and on their seasonal occurrence analysed by $\chi^{2}$ test.

\begin{tabular}{lrccccccccc}
\hline \multicolumn{1}{c}{ Species } & \multicolumn{4}{c}{ Ečka } & \multicolumn{6}{c}{ Uzdin } \\
\cline { 2 - 11 } & $\mathrm{t}$ & $\mathrm{df}$ & $\mathrm{p}<$ & $\chi^{2}$ & $\mathrm{df}$ & $\mathrm{t}$ & $\mathrm{df}$ & $\mathrm{p}<$ & $\chi^{2}$ & $\mathrm{df}$ \\
\hline Trichodina acuta & 30.48 & 40 & $* \star \star$ & 16.2 & 15 & 34.77 & 46 & $* * *$ & 18.7 & 13 \\
Trichodina nobilis & 2.78 & 34 & $* *$ & 11.4 & 15 & & & & & \\
Trichodina nigra & 0.42 & 53 & & 0.9 & 15 & & & & & \\
\hline
\end{tabular}

Trichodinella epizootica and T. subtilis parasitised exclusively gills. On the contrary, the occurrence of Trichodina acuta was far more frequent on the skin than on the gills in both fish-ponds, and that preference appeared to be statistically significant (Table 1). In the Ečka fish-pond, Trichodina nobilis was found on both skin and gills (Figure 2) with a significant preference for skin (Table 1),

Figure 2. Prevalence (in \%) of trichodinids to the skin (s) and gills (g) in the Ečka fishpond in particular months (March - October). Te - Trichodinella epizootica;

Ta - Trichodina acuta; Tn - Trichodina nobilis. 
whereas in the Uzdin fish-pond it was not present on the gills (Figure 3). In contrast to these two species, Trichodina nigra was found on both target organs, ocassionally on the same individuals. However, the occurrence on both organs in the same individuals appeared to be random $\left(\chi^{2}=4.850 ; \mathrm{df}=14\right)$ and there was no preference for either of the organs (Table 1).

Figure 3. Prevalence (in \%) of trichodinids to the skin (s) and gills (g) in the Uzdin fish-pond in particular months (March - October). Te - Trichodinella epizootica; Ta - Trichodina acuta; Tn - Trichodina nobilis.

Apparently, particular trichodinid species favoured either the skin or the gills. However, although Trichodinella epizootica was found exclusively on the gills of carp fry on this occasion, Stein (1984) and Lom \& Dykova (1989) recorded it on the skin, as well. Trichodina acuta and Trichodina nobilis were more frequent on the skin than on the gills of carp fry. Other sources reported these trichodinids occurring also on the skin, gills and nasal pits of freshwater fish (Golemansky \& Grupcheva 1975; Lom \& Dykova 1989). Nevertheless, according to $\chi^{2}$-test values (Table 1), a strong prevalence of Trichodina acuta and Trichodina nobilis was revealed for the skin, in comparison to the gills. 
Acta Veterinaria (Beograd), Vol. 53. No. 1, 41-46, 2003.

Nikolić Vera et al. Preference of trichodinids (Ciliata, Peritrichia) occurring on

fish-pond carp for particular organs and some morphological implications

The strongest effect noticed on target organs was that of Trichodinella epizootica. It damaged the gill epithelia and induced enforced mucous secretion, causing impaired gill function. The light microscopy examination of the gills of carp from the Uzdin fish-pond revealed moderately altered structure when invaded by trichodinids (Figure 4). Trichodinids were located between secondary lamellae, or on the top of the (sometimes shortened) secondary lamellae. Although most gills examined were functionally normal, certain changes of gill structure were regularly noticed, e.g. subepithelial oedema of the secondary epithelium, focal hyperplasia between secondary lamellae, curling of pillar cell system and mild circulatory changes, together with hypertrophy and hyperplasia of chloride and mucous cells. It is likely that those moderate gill alterations were not induced exclusively by

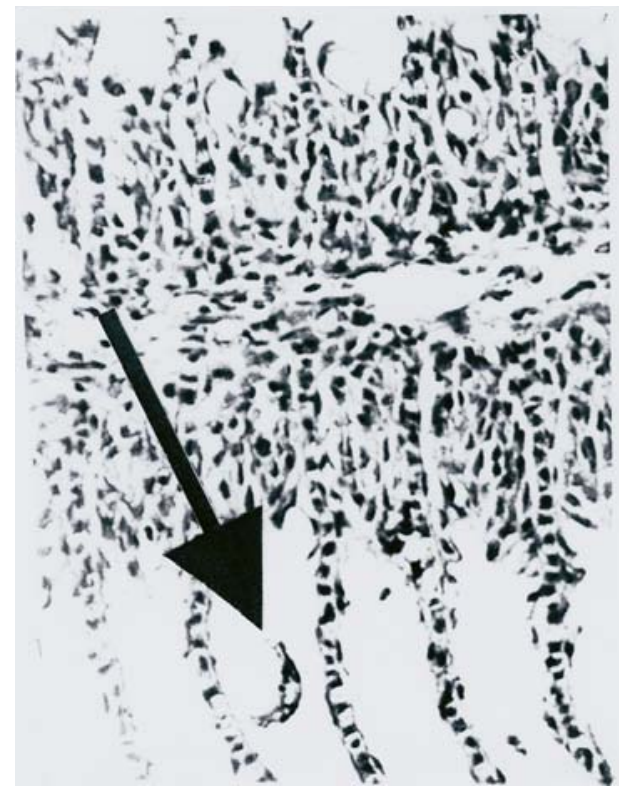

Figure 4. Gills of carp from the Uzdin fishpond invaded by Trichodinella epizootica, indicated by arrow. HE x 100. trichodinids, since they coincided with unfavourable environmental conditions in the fish-ponds, i.e., low dissolved oxygen concentration, high water temperature, high stock density, etc., which could also lead to increased mortality of fish fry in the rearing ponds (BykovskayaPavlovskaya 1964; Kabata 1985).

Address for correspondence:

Dr Vera Nikolić

Faculty of Biology, Institute of Zoology,

Studentski trg 16,

11001 Belgrade, Serbia \& Montenegro

\section{REFERENCES}

1. Allamuratov $B A, 1986$, Parasitic Protozoa and parasitic diseases of some fish ponds of Uzbekhistan and Kazakhstan, Karakalpakstan, Nukus. (in Russian).

2. Bauer ON, Musselius VA, Strelkov YA, 1973, Diseases of pond fishes. Israel Program for Scientific Translations, Jerusalem.

3. Bykovskaya-Pavlovskaya IE, 1964, Key to parasites of freshwater fish of USSR. Israel Program for Scientific Translations, Jerusalem.

4. Golemansky V, Grupcheva G, 1975, Recherches sur les parasites unicellulaires des poisson herbivores annuels en Bulgarie, Acta zool Bulgarica, 2, 3-14. (In Bulgarian) 
5. Grupcheva G, Golemansky V, 1986, Protozoan parasites on fishes in southwest Bulgaria. Fauna of southwest Bulgaria 1, 130-4. (In Bulgarian)

6. Halmetoja A, Valtonen ET, Taskinen J, 1992, Trichodinids (Protozoa) on fish from four central Finnish lakes of differing water quality. Aqua Fennica, 22, 59-70.

7. Kabata Z, 1985, Parasites and diseases of the fish cultured in the tropics. Taylor \& Francis, London and Philadephia.

8. Lom J, Dykova A, 1989, Protozoan parasites of the reared fish, Vytiskly Moravske tiskarske zavody, u.p., Kyjov. (In Czech).

9. Nikolić VP, Simonović PD, 1996, A survey of ciliate freshwater fish-parasite fauna in Serbia. Abstract. IUBS International Workshop on Freshwater Biodiversity. Balatonfured, 37.

10. Roberts RJ, 1978, Fish pathology. Bailliere Tindall, London.

11. Sokal RR, Rohlf FJ, 1981, Biometry, 2nd edn. W.H. Freeman and Company, San Francisco.

12. Stein GA, 1984, (Order Peritrichida. Suborder Mobilina). In: Key to parasites of freshwater fishes of the USSR (ed. by Shulman S.S.), 321-89. Leningrad (In Russian).

13. Tlenbekova NK, Dzevickaya NJ, 1986, Parasitic Protozoa of the 0+ fingerling of reared fish in the Cylik fish-pond, Ph.D. Thesis. 19th Conference, Ashabad. (In Russian).

\section{PREFERENCA TRIHODINIDA (Ciliata, Peritrichia) DETEKTOVANIH NA RIBNJAČKOM ŠARANU PREMA POJEDINIM ORGANIMA I NEKE MORFOLOŠKE IMPLIKACIJE}

NIKOLIĆ VERA, SIMONOVIĆ P i POLEKSIĆ VESNA

\section{SADRŽAJ}

U ovom radu su izneti rezultati ispitivanja preference nekih trihodinida prema koži ili škrgama ribnjačkog šarana. Razlika u lokalizaciji analizirana je uz pomoć Mann-Whitney U i $\chi^{2}$ testa. Za histološka ispitivanja škrge su fiksirane u $4 \%$ formaldehidu i dalje preparovane standardnim tehnikama. Trichodinella epizootica i T. subtilis parazitiraju isključivo na škrgama. Prisustvo vrste Trichodina acuta je statistički značajno češće na koži nego na škrgama. Trichodina nobilis je statistički značajno više zastupljena na koži nego na škrgama, dok je vrsta Trichodina nigra prisutna u sličnom procentu na oba organa. Utvrđeno je da vrsta Trichodinella epizootica oštećuje škržni epitel i uzrokuje pojačanu sekreciju mukusa. 